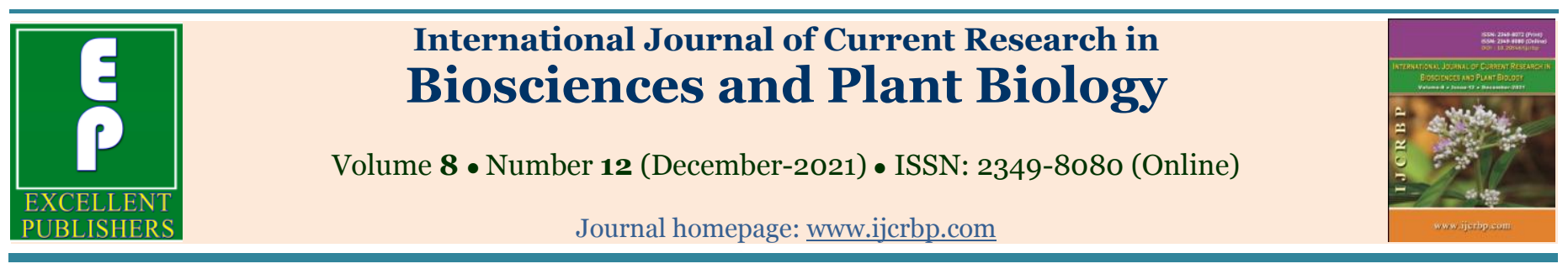

Original Research Article

doi: https://doi.org/10.20546/ijcrbp.2021.812.003

\title{
Effects of gibberellic acid on the stem and root growth patterns of Abelmoschus esculentus
}

\author{
Sanjeev Lal ${ }^{\mathbb{E} *}$, Aradhna Chauwan, Vipin Chandra
}

Department of Botany, R.C.U. Government P.G.College, Uttarkashi (Uttarakhand), India

*Corresponding author; e-mail: sanjeevlal1983@gmail.com

\begin{tabular}{|c|c|}
\hline Article Info & Abstract \\
\hline $\begin{array}{l}\text { Keywords: } \\
\text { Abelmoschus } \\
\quad \text { esculentus } \\
\text { Gibberellic acid } \\
\text { Phytohormones } \\
\text { Plant growth }\end{array}$ & $\begin{array}{l}\text { The seeds of Abelmoschus esculentus were grown in sandy loam soil of three field plots for the } \\
\text { treatment of } \mathrm{GA}_{3} \text { hormone concentration such as control plot }(\mathrm{A}) \text {, no treatment was given to this plot. } \\
\text { Plot }(\mathrm{B}) \text { was treated by } \mathrm{GA}_{3}\left(10^{-2} \mathrm{M}\right) \text { concentration and plot }(\mathrm{C}) \text { was treated by } \mathrm{GA}_{3}\left(10^{-3} \mathrm{M}\right) \\
\text { concentration daily and compared to the control field plot. The plants of Abelmoschus esculentus, for } \\
\text { the growth analysis were taken regularly and randomly at the } 15 \text { days interval from the seedling } \\
\text { emergence stage till to maturity. The length of Abelmoschus esculentus stem and root growth pattern } \\
\left(\text { Okra) was observed with two concentrations of these plant hormones such as } \mathrm{GA}_{3}\left(10^{-2} \mathrm{M}\right) \text { and } \mathrm{GA}_{3}\right. \\
\left(10^{-3} \mathrm{M}\right) \text { ) concentration and to evaluate the best concentration of these growth regulators as }\left(\mathrm{GA}_{3}\left(10^{-}\right.\right. \\
\left.{ }^{3} \mathrm{M}\right) \text { ) only, which showed the maximum stem and root length of the Abelmoschus esculentus as } \\
\text { compared to the control. }\end{array}$ \\
\hline
\end{tabular}

- Received: 24 October 2021 • Revised: 30 November 2021 • Accepted: 2 December 2021 • Published Online: 6 December 2021

\section{Introduction}

The present study was on the vegetable crop species such as Abelmoschus esculentus (Okra), because these provide not only good nutrition, but also possible therapeutic benefits for the human kind. Healthy dietary patterns comprising of fruit, vegetables, legumes and nuts has a positive effect on the physical and mental health. Also the 2015 US dietary guideline committee found that vegetables and fruit are only dietary elements that proved beneficial in preventing or treating an array of diseases. These plant species decline to a great extent due to the change in environmental conditions and less adaptability, lack of nutrient in soil, less growth and productivity of plants and lastly the stress. These all problems in some extent can be solved by using of a small quantity of some plant growth regulators. It has been well established that the plant growth hormone influence the growth and developments of plants. These chemical substances are able to coordinate growth among different plant part or physiological and biochemical processes. Gibberellins are commonly used in the agriculture and were first isolated from the metabolite products of the rice (Oryza sativa) pathogenic fungus as Gibberella fujikuroi observed in 1938. GA3 are a group of plant hormones produced by the leaves of modern plant and developing the peaks in the root and stem. Gibberellic acid initiates the elongation of plant cells and increases the production of side branches and floral parts. It also increases the 
number of flower and fruits and increases their growth. When gibberellic acid sprayed on the plant, has physiological effects on plant growth and its role in the process of photosynthesis and activate other vital activities and increasing plant height and size of the leaves, root and increased productivity.

The most important functions of the plant hormones is controlling and coordinating cell division, growth and differentiation. Plant hormones can affect different plant activities including seed dormancy and germination (Graeber et al., 2012). Plant hormones including abscisic acid (ABA), ethylene, gibberellins, auxin (IAA), cytokinins and brassinosteroids are biochemical substances controlling many physiological and biochemical processes in the plant. These products are produced by plants and also by soil microbes (Finkelstein et al., 2004; Jimenez et al., 2005). Treatments of $\mathrm{GA}_{3}$ and IAA are mostly preferred chemicals among all plant growth regulators in seed germination of plants, because of revealed physiological effects on the seed germination. Auxin is an important plant growth hormone which is active in the regulation of most growth processes in plants. However, its role in the germination of seeds is largely unknown, while it is well known that gibberellins and cytokinins are of important for the germination processes as was noted by Khan et al. (1971).

In most of the naturally vegetative propagated species adventitious root formation is there without any need for hormone treatments, while other require different growth regulators usually auxin was noted by Syros et al. (2004). Plant growth hormones have also been reported to affect seed germination and dormancy by affecting different parts of the seeds. Though there are some reports on affect of hormones for rooting in cuttings, but such effects are genotype specific and before going for mass application, study needs to be conducted on the selected genotype to find out the optimum dose for hormone application. Seed germination is the most important sensitive stage to stress, so that early seedling growth and final cop yield can be inhibited by effects of salinity. $\mathrm{GA}_{3}$ had stimulant effects on germination rate and root to shoot ratio in Kimia (Khajoor) genotypes. It is well known that uses of $\mathrm{GA}_{3}$ had positive response for germination percentage as was observed by Shohani et al. (2014). The gibberellins helps in the cell growth of stem, leaves and other aerial parts of by causing cell elongation and increase in intermodal length. A higher concentration of gibberellins increases plant growth as was noted by Bora and Sharma et al. (2006), while higher concentration of auxin inhibit it. Thus only low doses of auxin are effective in growth promotion as was noted by Vwioko and Longe et al. (2009).

Plant growth hormone is extensively used in the horticulture crop to enhance plant growth and improve yield by increasing fruit number, fruit set and size. Plant growth regulators like promoters, inhibitors or retardants play a key role in the controlling internal mechanisms of plant growth by interacting with key metabolic processes such as Nucleic acid metabolism and protein synthesis. Uses of plant growth regulators (PGRs) might be a useful alternative to increase crop production. Recently, there has been global realization of the important role of PGR's in increasing crop yield. $\mathrm{GA}_{3}$ is a group of plant hormones that control developmental processes such as germination, shoot elongation; tuber formation, flowering and fruit set and also promote growth in diverse plant species.

The most widely plant growth regulator is $\mathrm{GA}_{3}$ or gibberellic acid, which induces stem and internodes elongation and seed germination, enzyme production during germination and fruit setting and growth as was observed by Davies et al. (1995). Gibberellic acid is an important growth regulator that may have many uses to modify the growth, yield and yield contributing characters of plants as was noted by Rafeekher et al. (2002). Gibberellins regulate seed germination, growth of root and shoot (leaves and stem), the transition from the vegetative to the reproductive state, including floral apex induction, sex expression, organ growth within the developing flower and fruit set. Pollen germination and pollen tube growth are also controlled by $\mathrm{GA}_{3}$, as fruit growth. Finally, the GAs can delay fruit senescence and regulate seed and embryo growth. Gibberellins are also important regulators of flowering in cereals and grasses. IAA and $\mathrm{GA}_{3}$ are produced by apical bud. Thus it is conceivable that internodes elongation is modulated by the apex by way the effect of $\mathrm{GA}_{3}$ and IAA on cell division on one hand and by their synergistic effects on cell elongation on the other. The effect of $\mathrm{GA}_{3}$ in dwarf pea enhanced internode elongation when applied separately.

Okra (Abelmoschus esculentus) is widely grown primarily for its soft immature fruit or pods. The pods contain a glutinous, sticky substance that is used to thicken soups and stews. They are boiled or fried and 
eaten as vegetable. They can also be cut into pieces, dried and or powdered and stored for use in soups during the dry season when fresh okra fruits are scarce. The young leaves are also boiled and used in soups as was recorded by Norman et al. (1992). The leaves are further used for the medicinal purposes. The okra leaves as a curative medicine against ulcers is serious bleeding inside a human body. Okra leaves promotes digestion since it has considerable amount of roughages. The seeds can be used as a source of edible oil as well as in the soap industry as was observed by the Oyolu et al. (1983). The present investigation is being carried out to study the promotory effects of gibberellins hormone concentrations on the Abelmoschus esculentus belongs to the family Malvaceae. These vegetable species was treated with two concentrations of $\mathrm{GA}_{3}$ such as $\left(10^{-2} \mathrm{M}\right)$ and $\left(10^{-3} \mathrm{M}\right)$ respectively. The stem and root growth patterns of Abelmoschus esculentus enhanced by the sprayed of $\mathrm{GA}_{3}\left(10^{-3} \mathrm{M}\right)$ better than to the $\mathrm{GA}_{3}\left(10^{-2} \mathrm{M}\right)$ concentration as compared to the control.

In the present research work, promotory effects of plant Growth Regulator viz. $\mathrm{GA}_{3}$ has been aimed to study on Okra vegetables in the field study. Though, a number of references are available regarding promotory effects of plant growth hormone on various morphological physiological and biochemical parameters as evidenced from the different workers. Therefore, present study was being proposed to evaluate the individual effects of $\mathrm{GA}_{3}$ concentrations to enhance the some morphological parameters of the Abelmoschus esculentus and compared to the control during field studies with the following major objectives: (i) moisture content and water holding capacity (soil moisture content of field plots; soil composition; water holding capacity of study plots), and (ii) plant growth patterns (stem length and root length (cm) of Abelmoschus esculentus).

\section{Materials and methods}

A) General experimental design: During field studies the following experimental design were taken into consideration:

Control: Seeds of Abelmoschus esculentus were soaked for $24 \mathrm{~h}$ in distilled water in order to check the good quality of seeds. Those seeds are bad quality seeds. Then put the seeds in $0.1 \%$ of $\mathrm{HgCl}_{2}$ for sterilization and placed in the petridishes for the sowing in the field plots.
Plant growth hormone: Test solution of $\mathrm{GA}_{3}$ were prepared in $\left(10^{-2}\right.$ and $\left.10^{-3}\right) \mathrm{M}$ concentrations and treated on Abelmoschus esculentus. The seeds of Abelmoschus esculentus were soaked for $24 \mathrm{~h}$ in $\mathrm{GA}_{3}\left(10^{-2}\right.$ and $\left.10^{-3}\right)$ $\mathrm{M}$ concentration of plant growth hormone and soaked seeds were placed in Petri dishes for the sowing in the field plots.

(B) Edaphic condition: Certain physical and chemical properties of soil of the study plots were analyzed for the present investigation.

(C) Moisture content of soil: Took $10 \mathrm{~g}$ soil of study area from a depth of $20-30 \mathrm{~cm}$ in the empty glass beaker. After that measure the weight of soil with beaker. Now the beaker with soil was kept in the microwave oven at the temperature of $10^{\circ} \mathrm{C}$ for $24 \mathrm{~h}$. The calculations were done using the following formula.

$\%$ of moisture content of soil $=\left(\mathrm{W}_{1}-\mathrm{W}_{2} / \mathrm{W}_{2}-\mathrm{W}\right) \times 100$

(D) Water holding capacity of soil: Five gram of soil was taken from the study area from a depth of $20-30 \mathrm{~cm}$. To it $20 \mathrm{ml}$ of water was added in a burette allow the passage of water from the burette in a beaker. The water which will be unabsorbed by the soil will come down in the beaker. By measuring the amount of unabsorbed water and calculated the water holding capacity of soil as per the given formula.

$$
\text { Water absorbed by soil }=(\mathrm{V} / \mathrm{W}) \times 100
$$

\section{Treatments of the field plots}

The details of treatment are given in Table 1. The seeds of the Abelmoschus esculentus (Fig. 1a) were sown in the given design field plots (Fig. 1b) and treated as follows:

1. Plot-A was taken as control. No treatment was given to the Abelmoschus esculentus of this plot.

2. Plot-B was sprayed daily with $\mathrm{GA}_{3}\left(10^{-2}\right) \mathrm{M}$ concentration on the Abelmoschus esculentus daily.

3. Plot-C was sprayed daily with $\mathrm{GA}_{3}\left(10^{-3}\right) \mathrm{M}$ concentration on the Abelmoschus esculentus daily.

Table 1. Experimental design in the laboratory.

\begin{tabular}{llll}
\hline \hline Treatments & Control & $\mathbf{G A}_{3}$ & $\mathbf{G A}_{3}$ \\
\hline Concentration & -- & $\left(10^{-2}\right) \mathrm{M}$ & $\left(10^{-3}\right) \mathrm{M}$ \\
\hline
\end{tabular}




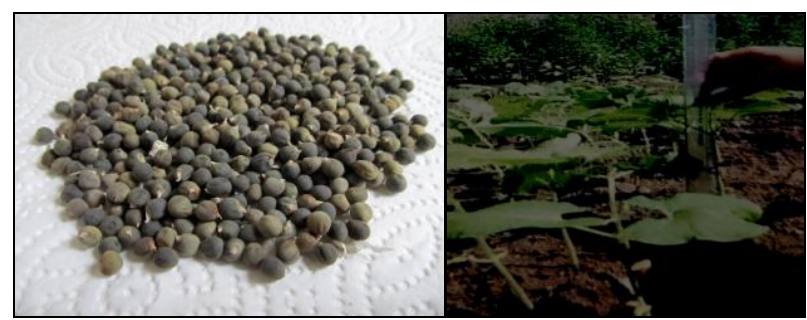

(a)

(b)

Fig. 1: (a) Seeds of Abelmoschus esculentus; (b) Measurement of Stem growth patterns of Abelmoschus esculentus.

\section{Description of study area}

The study site was located in Ram Chandra Uniyal Govt. P.G.College, Uttarkashi region of Uttarakhand state. Uttarkashi District is a district of Garhwal division of the Uttarakhand state in northern India and has its headquarters at Uttarkashi city. Uttarkashi is located at $30.73^{\circ} \mathrm{N} 78.45^{\circ} \mathrm{E}$ (Fig. 2).

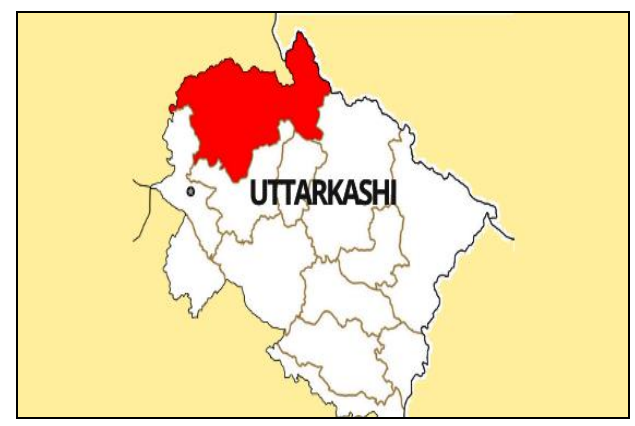

Fig. 2: Map of study area.

It has an average elevation of 1,165 meters (4,436 feet) and most of the topography is hilly. Uttarkashi District town lies high in the Himalaya range and the district contains the source of both the Ganges from Gangotri and Yamuna from Yamunotri rivers, which attract thousands of Hindu pilgrims. The town lies on the main route to Gangotri, has many Hindu temples and is also considered an important Hindu pilgrimage centre. The district is bounded on the north by Himachal Pradesh state, on the northeast by Tibet, on the east by Chamoli District, on the southeast by Rudraprayag District, on the south by Tehri Garhwal District and on the west by Dehradun District. Uttatkashi it means North Kashi it's one of the favorite place of Lorad Shiva call this Kashi Biswanaath. In the present study the protease and peroxidase activity was also enhanced in the germinating seeds of both varieties of mustard crops due to the UV-B exposure as compared to the control, when the seeds were supplied with plant hormones (PGRs) with UV-B treatment, which changed significantly and decreased in Brassica compestris and Brassica juncea respectively as compared to UV-B exposure only.

\section{Results and discussion}

The present investigation has been carried out the uniformly seeds of the variety of Abelmoschus esculentus were selected and soaked in the distilled water for $6 \mathrm{~h}, 12 \mathrm{~h}$ and $24 \mathrm{~h}$ respectively. After some time these presoaked seeds were spread in the Petri dishes and sown in the plots. Plot (A) was kept as control condition, i.e. not sprayed by plant growth hormone and plot (B) was sprayed by $\mathrm{GA}_{3}\left(10^{-2}\right) \mathrm{M}$ concentration and plot $(\mathrm{C})$ was sprayed by $\mathrm{GA}_{3}\left(10^{-3}\right) \mathrm{M}$ concentration daily as compared to control. After giving the different treatments to the seedlings the development of stem and root growth activity was measured and compared as described in the materials and methods.

The seeds of Abelmoschus esculentus (okra) were sowed in the sandy loam and clay loam soil (Table 2). The minimum and maximum temperature prevailed during the study period is given in Table 3 . The plant samples for growth analysis were taken regularly at the $10^{\text {th }}$ day interval from the each plot separately, after the seedling emergence (two leaf stage) till to 40 and 50 days. For each field plot study, the five phenotypically identical plants were taken from field plot carefully to laboratory, where these washed by running water to remove the soil particles, using a mesh of $0.32 \mathrm{~nm}$ pore size and tap water current. The growth measurements were taken on the basis of stem and root of Abelmoschus esculentus plants, for the each treatment separately. The mean values of 5 plants of each sample plot (A), (B) and (C) were calculated and represented with \pm S.D.

Stem growth patterns of the Abelmoschus esculentus: The data of stem growth patterns as improved by the treatments are presented in the Fig. 3. in the control plot (A), the value of stem length $(\mathrm{cm} / \mathrm{pl})$ were recorded at the tenth $\left(10^{\text {th }}\right)$ day stage of growth as $3.6(\mathrm{~cm} / \mathrm{pl})$ and observed to be increased continuously up to the 40 days and noticed as ca. $19.5(\mathrm{~cm} / \mathrm{pl})$, while plot (B) was sprayed by $\mathrm{GA}_{3}\left(10^{-3}\right) \mathrm{M}$ concentration daily, the enhancement was observed to stem length as compared to control. The maximum promotion in length was noticed at the $10^{\text {th }}$ day stage of growth and recorded as ca. $75 \%$, at the $20^{\text {th }}$ day recorded as ca. $58 \%$, at the $30^{\text {th }}$ day ca. $46 \%$ and at the $40^{\text {th }}$ day ca. $30.7 \%$, as compared to the control. 
Table 2. Physical properties of soil samples collected at the study area: Soil texture (Physical properties).

\begin{tabular}{ll}
\hline Sand $(\%)$ & $55 \%$ \\
Slit $(\%)$ & $18 \%$ \\
Clay $(\%)$ & $27 \%$ \\
$\mathrm{pH}$ & 7.5 \\
Water holding capacity $(\%)$ & $160 \%$ \\
Moisture content $(\%)$ & $23.15 \%$ \\
\hline
\end{tabular}

Table 3. Temperature of the study area during the period January to June.

\begin{tabular}{lll}
\hline \multirow{2}{*}{ Months } & \multicolumn{2}{c}{ Temperature $\left({ }^{\circ} \mathbf{C}\right)$} \\
\cline { 2 - 3 } & Maximum & Minimum \\
\hline January & 25 & 13 \\
February & 29 & 21 \\
March & 38 & 22 \\
April & 43 & 26 \\
May & 43 & 34 \\
June & 46 & 30 \\
\hline
\end{tabular}

The root growth patterns were also recorded from the $10^{\text {th }}$ day stage up to 40 days in terms of length and data was depicted in the Table 4 . In the control plot, the value of length of root was found at the $10^{\text {th }}$ stage and recorded as ca. $3.5(\mathrm{~cm} / \mathrm{pl})$ and observed continuously up to 40 days. When these plants were sprayed to plant growth regulators such as $\mathrm{GA}_{3}$ daily, the significant promotion was also found as compared to control plot. When the plants of plot (B) were studied along with $\mathrm{GA}_{3}\left(10^{-3}\right) \mathrm{M}$ concentration, a significant promotory effects were observed on the root length, from the $10^{\text {th }}$ day stage till to 40 days and increased by ca. $2.8 \%$, $1.9 \%, 5.5 \%$ and $0.8 \%$ as compared to the control plot.

The present investigation has been carried out to study the effects of plant growth hormone such as $\mathrm{GA}_{3}$ when applied on the some morphological characters of Abelmoschus esculentus. It has been observed that when plant growth hormone concentration applied which enhanced the stem and root growth patterns of Abelmoschus esculentus as compared to control.The similar observation was also identified by Graeberat et al. (2012) and Bialek et al. (1991). Various workers in different crop plants have also been reported that the promotory effects of plant growth regulators on the root and stem respectively. In the control plot the value of stem length $(\mathrm{cm} / \mathrm{pl})$ were recorded at the tenth (10) day stage of the growth as $3.6(\mathrm{~cm} / \mathrm{pl})$ and observed to be increased continuosly up to the 40 days and noticed as ca. $19.5(\mathrm{~cm} / \mathrm{pl})$, while the other plot was sprayed by $\mathrm{GA}_{3}\left(10^{-3}\right)$ concentarion daily, the enhancement was observed on stem length as compared to control. The maximum promotion in length was noticed at the $10^{\text {th }}$ day stage of growth and recorded as ca. $75 \%$ at the $20^{\text {th }}$ day as ca. $58 \%$ at the $30^{\text {th }}$ day as ca. $46 \%$ and at the $40^{\text {th }}$ day ca. $30.7 \%$ respectively. These results are with the conformity of Naeem et al. (2004), Rafeekher et al. (2002) and Davies et al. (1975).

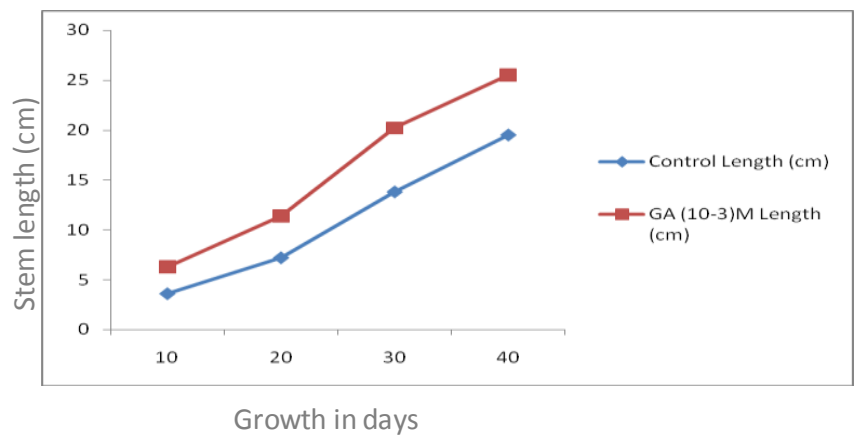

Fig. 3: Stem growth patterns of field grown Abelmoschus esculentus increased by plant growth hormone such as GA $\left(10^{-3}\right) \mathrm{M}$ concentration.

Table 4. Root growth patterns of field grown Abelmoschus esculentus increased by plant growth hormone such as GA $\left(10^{-3}\right) \mathrm{M}$ concentration.

\begin{tabular}{lllll}
\hline \multirow{2}{*}{ Treatments } & \multicolumn{4}{l}{ Length $(\mathbf{c m})$ of root growth in days } \\
\cline { 2 - 5 } & $\mathbf{1 0 ~ d}$ & $\mathbf{2 0 ~ d}$ & $\mathbf{3 0 ~ d}$ & $\mathbf{4 0 ~ d}$ \\
\hline Control & $3.5 \pm$ & $4.08 \pm$ & $9.0 \pm$ & $12.5 \pm$ \\
& 1.65 & 2.04 & 3.20 & 2.55 \\
$\mathrm{GA}\left(10^{-3}\right) \mathrm{M}$ & $3.6 \pm$ & $4.16 \pm$ & $9.5 \pm$ & $12.6 \pm$ \\
& 1.51 & 1.41 & 3.20 & 2.55 \\
\hline
\end{tabular}

In the control plot the value of length of root was found at the $10^{\text {th }}$ day stage and recorded as ca.3.5 $(\mathrm{cm} / \mathrm{pl})$ and observed up to 40 days. When these plants were sprayed to plant growth hormone such as $\mathrm{GA}_{3}\left(10^{-3}\right)$ daily, the significant promotory effects were observed on the root length from the $10^{\text {th }}$ day stage till to 40 day stage and increased by ca. 2.8\%, $1.9 \%, 5.5 \%$ and $0.8 \%$ respectively as compared to the control plot. These results are with the conformity of Arney and Mancinelli et al. (1967).

\section{Conclusions}

The present study was concluded that to investigate the stem and root growth patterns of the Abelmoschus esculentus were enhanced by the $\left(\mathrm{GA}_{3} 10^{-3} \mathrm{M}\right)$ hormone concentration but not better enhancement was not observed in the $\left(\mathrm{GA}_{3} 10^{-2} \mathrm{M}\right)$ hormone concentration. After 10 days of the germination, the length of stem of Abelmoschus esculentus to be increased continuously with these plant growth hormone concentration $\left(\mathrm{GA}_{3} 10^{-3}\right.$ 
M) sprayed daily for the growth of stem and root in field plots and compared to the control plot. The significant result was observed in the root length of Abelmoschus esculentus, not maximum enhancement was noted, when treated by the $\left(\mathrm{GA}_{3} 10^{-3} \mathrm{M}\right)$ concentration of the hormone as compared to the control plot. Therefore crop plants as well as vegetables declined to a great extent due to change in environmental condition and less adaptability. Climatic variation and human activities are causing drought and land degradation. The decline in the agriculture productivity is causing hunger in major parts of the world. These all problems can be solved in some extent by using a small quantity of plant growth hormone concentrations. Unfortunately, our farmers have lack of knowledge about these plant growth hormones. They do not know its magical importance in crop production. So, the aim of my investigation is to aware farmers about these plant growth hormones and its role to increase the production of crop plants, resulting increases their economic growth.

\section{Conflict of interest statement}

Authors declare that they have no conflict of interest.

\section{Acknowledgement}

We are highly obliged to Professor Gulshan Kumar Dhingra, Pandit Lalit Mohan Govt. P.G. College Rishikesh, Department of Botany and Dr. M.P.S. Parmar, Department of Botany, R.C.U.Govt. P.G.College Uttarkashi for their kind support and help to carry out present work.

\section{References}

Arney, S.E., Mancinelli, P.A., 1967. Surgical investigations of the role of the IAA and GA in the elongation of "Meteor" pea internodes. New Phytol., 66, 271-283.

Bialek, K., Michalczuk, L., Cohen, J. D., 1991. Auxin metabolism in bean seedlings (abstract no.496). Plant Physiol., 96: S-77.

Bora, R. K., Sharma, C.M., 2006. Effect of gibberellic acid and Cycocel on growth, yield and protein content of Pea. Asian J. Plant Sci., 5: 324-330.

Davies, P. J., 1995. Plant Hormones, Physiology, Biochemistry and Molecular Biology. SpringerScience+Business Media, B.V.

Finkelstein, R.R., 2004. The role of hormones during seed development andgermination. In: Davies, P.J. (Ed.), Plant Hormones: Biosynthesis, Signal transduction. The Netherlands, Kluwer Academic Publishers, Dordrecht, pp.513-537.

Graebar, K., Nakabayashi, K., Miatton, E., LeubnerMetzger, G., Soppe, W., 2012. Molecular mechanisms of seed dormancy. Plant Cell Environ., 35: 1769-1786.

Jimenez, V.M., 2005. Involvement of plant hormones and plant growth regulators in vitro somatic embryogenesis. Plant Growth Regul., 47: 91-11.

Khan, A.A., 1971. Cytokinins: Permissive role in seed germination. Science, 171: 853-859.

Naeem, M., Bhati, I., Ahamad, R. H., Yasin Ashraf, M., 2004. Effect of some growth hormones $\left(\mathrm{GA}_{3}\right.$, IAA and Kinetin) on the morphology and early or delayed initiation of bud of lentil (Lens culinaris Medik). Pak. J. Bot. 36(4): 801-809.

Norman, J. C., 1992. Tropical vegetable crops. Arhur H. Stockwell Ltd., London, UK.

Oyolu, C., 1983. Okra Seeds, potential Source of high quality vegetable oil. Proc. $5^{\text {th }}$ Annual conference Horticulture Society Nigeria.

Rafeeker, M., Nair, S.A., Sorte, P.N., Hatwal, G.P., Chandan, P.N., 2002. Effect of growth regulators on growth and yield of summer cucumber. J. Soils Crops, 12(1): 108-110.

Shohani, F., Mehrabi, A.A., Khavarinegad, R.A., Safari, Z. and Kian, S., 2014. The effect of gibberellic acid (GA3) on seed germination and early growth of lentil seedlings under salinity stress. Middle-East J. Sci. Res, 19(7), pp.995-1000.

Syros, T., Yupsanis, T., Zafiriadis, H., Economou, A., 2004. Activity and isoform of peroxidases, lignin and anatomy, during adventitous rooting in cutting of Ebenus cretica L. J. Plant Physiol., 161: 69-77.

Vwioko, E.D., Longe, M.U., 2009. Auxin and gibberellin effects on growth and fruit size in Lagenaria siceraria (Molina standley). Biosci. Res. Comm., 21: 263-271.

\section{How to cite this article:}

Lal, S., Chauwan, A., Chandra, V., 2021. Effects of gibberellic acid on the stem and root growth patterns of Abelmoschus esculentus. Int. J. Curr. Res. Biosci. Plant Biol., 8(12): 17-22.

doi: https://doi.org/10.20546/ijcrbp.2021.812.003 